\title{
Structure and Chemistry of Walls of Rods, Cocci and Cystites of Arthrobacter globiformis
}

\author{
By T. DUXBURY* AND T. R. G. GRAY† \\ Hartley Botanical Laboratories, University of Liverpool, P.O. Box 147 , Liverpool L69 $3_{B X}$ \\ AND G. P. SHARPLES \\ Department of Biology, Liverpool Polytechnic, Byrom Street, Liverpool
}

(Received I5 July 1977)

\begin{abstract}
Arthrobacter globiformis NCIBI0683 was grown under different conditions in continuous and batch culture to produce rods, cocci and cystites. All forms were resistant to lysozyme and enzyme LI and did not autolyse readily. Walls contained polysaccharide, made up of glucose, galactose and rhamnose, as well as peptidoglycan and phosphorus. The polysaccharide constituted about $60 \%$ of the wall of each form, although the molar ratios of glucose, galactose and rhamnose varied from $I: I: I$ in the cystites to $I: 3: 2$ in rods and I:3.5:3 in cocci. The molar ratios of alanine, glutamic acid, threonine and lysine in the peptidoglycan were similar in all three preparations (4:I:I:I). Electron microscopy showed that the wall was structurally homogeneous but was thicker in cocci (Io to $27 \mathrm{~nm}$ ) than in rods (6 to $I 2 \mathrm{~nm}$ ). The wall in cystites varied in thickness (6 to $40 \mathrm{~nm}$ ) and was sometimes distorted due to the accumulation of large amounts of glycogen which expanded the organism and displaced the ribosomes from most parts of the organism. Glycogen granules were also seen in rods but never in cocci. Division of Arthrobacter was by binary fission and budding. Buds could usually be distinguished from parent organisms since the latter contained less ribosomes and mesosomes. Large periplasmic spaces were found, especially in budding cells. Cross-wall formation differed in binary fission and budding.
\end{abstract}

\section{INTRODUCTION}

Arthrobacter strains characteristically change their morphology during growth, from rods into cocci. Rods predominate in young cultures while cocci are characteristic of the later stages of batch cultures (Mulder \& Antheunisse, 1963). In media where there is a very high carbon to nitrogen ratio, the cells may be further transformed into enlarged, oval or lemon-shaped cells, called cystites. The latter have been described as involution or senescent forms (Stevenson, 1963), as having a reproductive function (Chaplin, 1957) or as being cells in which abnormal accumulation of storage compounds has taken place (Mulder \& Zevenhuizen, I967).

Luscombe \& Gray (197I, I974) showed that the transformation of rods into cocci depended upon the growth rate of the culture and, in particular, that rods were characteristic of cultures growing rapidly. They showed that transformation of rods into cocci occurred at a characteristic dilution rate in a chemostat under either carbon- or nitrogen-limiting conditions. Cystite-like structures can also be produced by growing organisms very slowly in a chemostat under nitrogen-limiting conditions (S. J. Chapman, personal communication).

\footnotetext{
* Present address: Department of Microbiology, University of Sydney, Sydney 2006, New South Wales, Australia.

$\dagger$ Present address: Department of Biology, University of Essex, Colchester, Essex $\mathrm{CO}_{4}{ }_{3} \mathrm{SQ}$.
} 
The ability of Arthrobacter species to survive long periods of starvation is well known (Gray, 1976) and cells can remain intact even after death (Luscombe \& Gray, 1974). This suggests that the wall may have properties preventing lysis or that autolytic enzymes are absent. This paper reports a study of the chemistry, structure and properties of all three morphological forms of the strain Arthrobacter globiformis NCIBI0683 isolated from a pineforest soil, and shown to be an abundant organism in this soil (Lowe \& Gray, 1972).

\section{METHODS}

Growth. Arthrobacter globiformis NCIBI0683 was grown at $25^{\circ} \mathrm{C}$ in a 2.71 Biotec fermenter (FLro3) at a dilution rate of $0.25 \mathrm{~h}^{-1}$ for production of rods and at $0.1 \mathrm{~h}^{-1}$ for cocci, using the simple salts base $\mathrm{E}$ medium (Owens \& Keddie, 1969) with added biotin (I $\left.\mu \mathrm{g} \mathrm{ml}^{-1}\right)$ and glucose $\left(0 \cdot 2 \mathrm{~g} \mathrm{l}^{-1}\right)$ as a limiting carbon source (Luscombe \& Gray, 1974). The bacteria were collected at $\mathrm{I}{ }^{\circ} \mathrm{C}$ and harvested by continuous centrifugation.

Cystites were produced by a modification of the method of Stevenson (1963). One $\mathrm{ml}$ of a $24 \mathrm{~h}$ nutrient broth culture was transferred to $50 \mathrm{ml}$ of PYEBG medium [bacteriological peptone, $5 \mathrm{~g}$; yeast extract, $4 \mathrm{~g}$; glucose, I g; basal salts medium (Lochhead \& Burton, 1954), $750 \mathrm{ml}$; water, $250 \mathrm{ml}$ in an Erlenmeyer flask and grown for $40 \mathrm{~h}$ at $25^{\circ} \mathrm{C}$ on a rotary shaker. Portions of this culture $(8 \mathrm{ml})$ were inoculated into 31 round-bottomed flasks containing 21 of Lochhead \& Burton (1954) basal medium with I \% (w/v) glucose. The cultures were aerated with compressed air passed through a sintered glass sparger and grown at $25^{\circ} \mathrm{C}$ for 4 days. The bacteria were cooled by pouring them on to crushed ice and centrifuged at $3000 \mathrm{~g}$ for $15 \mathrm{~min}$.

All cells were washed three times with deionized water and frozen at $-10{ }^{\circ} \mathrm{C}$ until required, or used at once for electron microscopy.

Measurement of autolytic activity. The behaviour of A. globiformis was studied, using Staphylococcus afermentans as a control. One $\mathrm{ml}$ of an overnight culture in nutrient broth was inoculated into $75 \mathrm{ml}$ of nutrient broth in a $250 \mathrm{ml}$ nepheloculture flask and incubated on a shaker at $25^{\circ} \mathrm{C}$. Staphylococcus afermentans and rods of $A$. globiformis were harvested when the rate of increase in turbidity indicated that they were in the exponential phase of growth. Both organisms were also harvested after incubation for 6 days when they had reached the stationary phase. Cystites of $A$. globiformis were produced as above. Cultures were centrifuged $(3000 \mathrm{~g}, \mathrm{I} 5 \mathrm{~min})$ without chilling, washed twice in sterile deionized water and once in

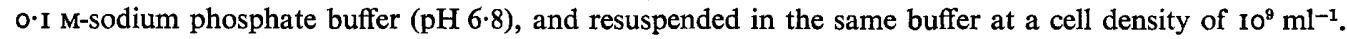
Autolysis was followed by using a nephelometer. Each treatment was used in triplicate.

Wall preparations were made as described below, although treatments with $\mathrm{NaCl}$ and trypsin were omitted so as not to disrupt autolytic enzymes. The walls were suspended in $0.0 \mathrm{I}$-sodium phosphate buffer (pH 6.8) to give an extinction of 0.6 to 0.7 . Autolysis was followed in a nephelometer at $25^{\circ} \mathrm{C}$.

Activity of egg white lysozyme and lytic enzyme LI from Cytophaga. Rods, cocci and cystites were prepared as for measurements of autolytic activity. A washed suspension $(2.5 \mathrm{ml})$ in $0.066 \mathrm{M}$-potassium phosphate buffer ( $\mathrm{pH} 6 \cdot 2$ ) was placed in a cuvette to give an $E_{450}$ of 0.6 to 0.7. Lysozyme (Sigma; 0. I ml solution containing 0.1 or $0.2 \mathrm{mg} \mathrm{ml}^{-1}$ ) in $0.066 \mathrm{M}$-potassium phosphate buffer $(\mathrm{pH} 6.2)$ was added and mixed by inversion. Decreases in $E_{450}$ at $25^{\circ} \mathrm{C}$ were recorded, as recommended by the manufacturers.

The action of $\mathrm{LI}$ enzyme (BDH; 5 to $100 \mu \mathrm{g} \mathrm{ml}^{-1}$ ) at $\mathrm{pH} 5.0$ and $25^{\circ} \mathrm{C}$ was followed in a nephelometer.

Preparation of walls. Bacteria were disrupted with glass beads in a Mickle tissue disintegrator (Mickle Laboratory Engineering, Gomshall, Surrey) (Work, I97I) and purified by the scheme outlined by Salton (1964). Purity was checked by comparing the ultraviolet absorption spectra of the walls with those of the cytoplasmic fractions and by electron microscopy of ammonium molybdate $(\mathrm{I} \%, \mathrm{w} / \mathrm{v})$ negatively-stained preparations. Purified walls were freeze-dried and stored until required over $\mathrm{P}_{2} \mathrm{O}_{5}$ in a vacuum desiccator.

Quantitative chemical analysis. (i) Phosphorus. Wall material (5 to $\mathrm{Io} \mathrm{mg}$ ) was analysed according to the method of Allen (1940).

(ii) Amino acids. Samples ( 5 to $8 \mathrm{mg}$ ) of wall material were hydrolysed in $6 \mathrm{M}-\mathrm{HCl}$ for $18 \mathrm{~h}$ at $110^{\circ} \mathrm{C}$ in sealed tubes under vacuum. Insoluble humin was removed by centrifuging and the supernatant was taken to dryness in a rotary evaporator at $60^{\circ} \mathrm{C}$ under reduced pressure. The residues were taken up twice in deionized water and dried to remove traces of acid, then passed through an ion-exchange resin (Amberlite IR-120H) and converted to $N$-trifluoroacetyl $n$-butyl esters (Gehrke et al., I968). Samples (5 to 10 $\mu$ l) were analysed on a Microtek GC 2000 R gas chromatograph.

(iii) Amino sugars. Amino sugars from acid hydrolysates $\left(4 \mathrm{M}-\mathrm{HCl}, 100{ }^{\circ} \mathrm{C}, 4 \mathrm{~h}\right)$ of wall material $(4$ to $6 \mathrm{mg}$ ) were determined according to the method of Stewart-Tull (1968).

(iv) Sugars. Total carbohydrate was determined by the phenol- $\mathrm{H}_{2} \mathrm{SO}_{4}$ method of Dubois et al. (1956) as described by Herbert, Phipps \& Strange (1971). Individual monosaccharides were determined by hydro- 
Table I. Chemical composition of walls of A. globiformis NCIBI0683

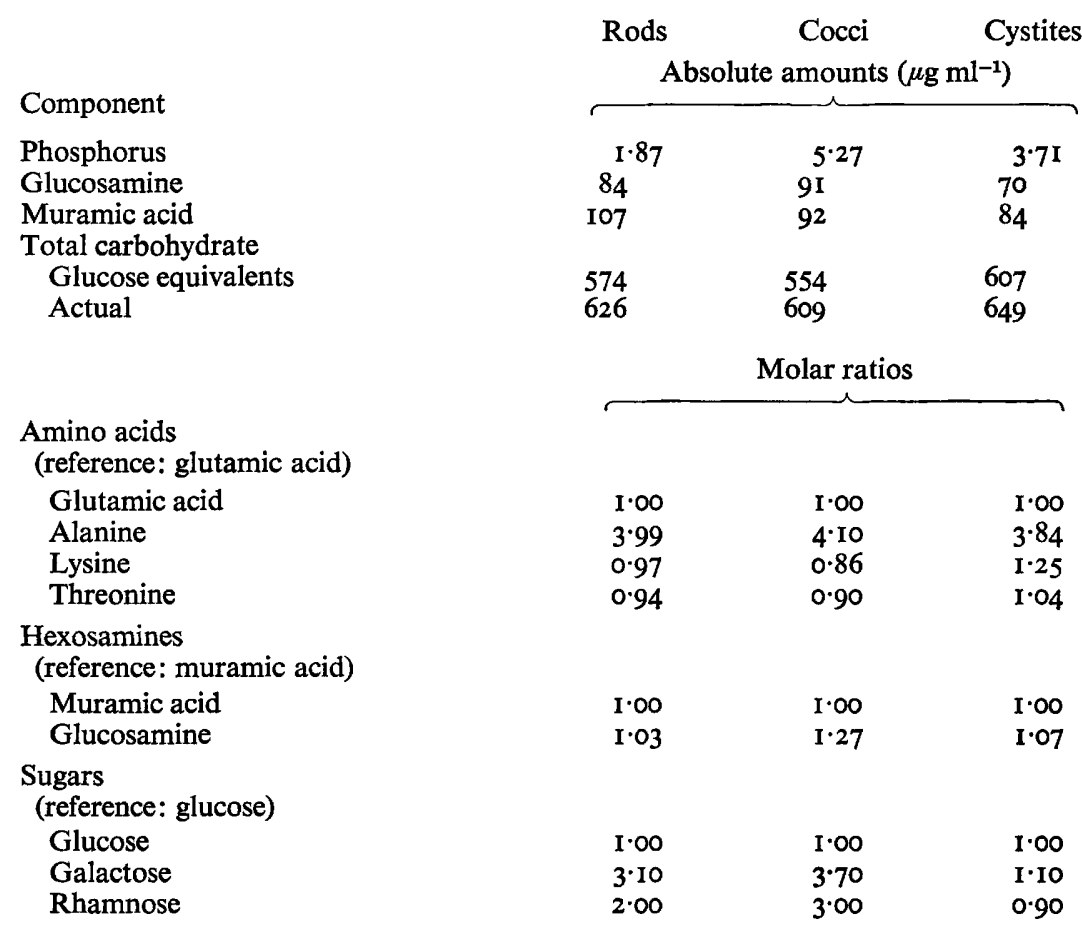

lysing I mg wall material in $\mathrm{I} M-\mathrm{H}_{2} \mathrm{SO}_{4}$ at $100{ }^{\circ} \mathrm{C}$ for $2 \mathrm{~h}$. The acid was neutralized with $\mathrm{BaCO}_{3}$ and the solids were separated by centrifuging and washed once with deionized water. The combined supernatants were dried in a rotary evaporator at $40^{\circ} \mathrm{C}$ under reduced pressure. Samples of the residues $(2$ to $5 \mu \mathrm{l})$ were analysed as their trimethylsilyl derivatives (Holligan \& Drew, 197I) on a Pye series 104 analytical gas chromatograph.

Electron microscopy. After being washed three times in deionized water, the bacteria were fixed in $1 \%$ $(\mathrm{w} / \mathrm{v}) \mathrm{OsO}_{4}$ in veronal buffer $(\mathrm{pH} 6 . \mathrm{I})$ for $16 \mathrm{~h}$. They were washed in buffer and in $0.5 \%(\mathrm{w} / \mathrm{v})$ uranyl acetate for 20 to $30 \mathrm{~min}$ and then suspended in $0.03 \mathrm{ml} 2 \%(\mathrm{w} / \mathrm{v})$ Oxoid ionagar no. 2 made up in veronal acetate buffer. The agar was cut into blocks ( 1 to $2 \mathrm{~mm}^{3}$ ) and dehydrated in ethanol. The specimens were embedded in Spurr's resin (Spurr, 1969) and sections were cut on an LKB Ultratome, and stained with $0.5 \%$ (w/v) uranyl acetate for $20 \mathrm{~min}$ followed by lead citrate for $5 \mathrm{~min}$ (Reynolds, 1963). Preparations were viewed with an AEI EM6B transmission electron microscope.

\section{RESULTS \\ Lysis of A. globiformis}

The rate of change of the turbidity of $A$. globiformis and Staphylococcus afermentans suspensions in buffer with time depended upon the physiological condition of the organisms. Stationary phase organisms were less prone to autolysis, showing 3\% (A. globiformis) and $30 \%$ (S. afermentans) decreases in turbidity in 5 days. In $A$. globiformis, the turbidity of suspensions of exponential phase rods or of cystites fell by $30 \%$ over the same period, while those of exponential phase $S$. afermentans fell by nearly $80 \%$. Suspensions of isolated walls of $A$. globiformis rods, cocci and cystites were stable in buffer for at least 4 days and showed no decrease in turbidity.

All morphological types of $A$. globiformis were resistant to lysozyme at 3.8 or $7.7 \mu \mathrm{g} \mathrm{ml}^{-1}$, and none of the suspensions showed a significantly greater decrease in turbidity than the controls. Rods of $A$. globiformis were also relatively resistant to Lr enzyme since, even at 

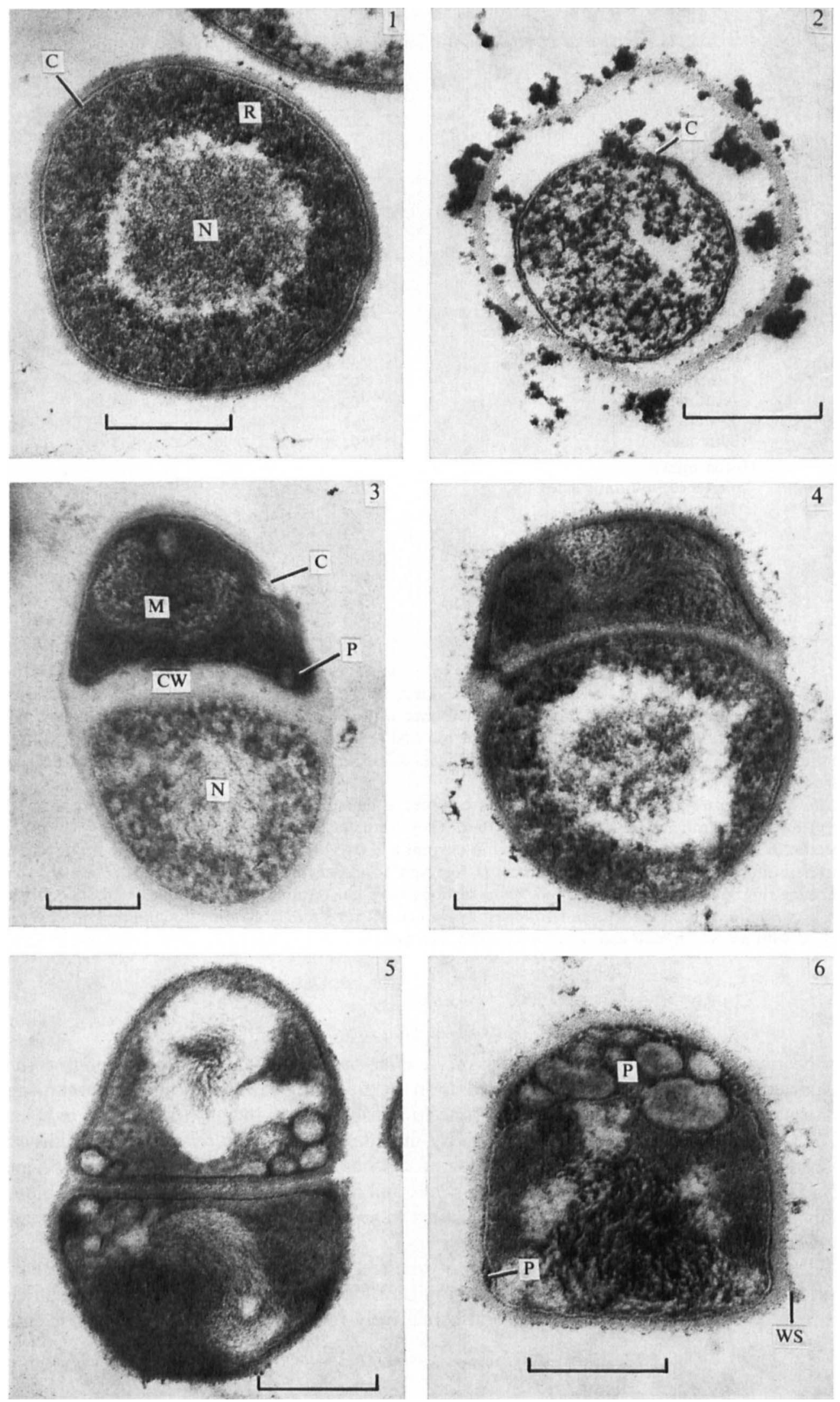
I00 $\mu \mathrm{g}$ enzyme $\mathrm{ml}^{-1}$, the turbidity of suspensions only fell by $\mathrm{I} \%$ in $2.5 \mathrm{~h}$ while the control decreased by $10 \cdot 2 \%$.

\section{Chemical composition}

The results of the chemical analyses of the walls of rods, cocci and cystites are shown in Table I. Phosphorus was found in the walls of all the morphological types, ranging from $\mathrm{I} \cdot 87 \mu \mathrm{g} \mathrm{mg}^{-1}$ in the rods to $5.27 \mu \mathrm{g} \mathrm{mg}^{-1}$ in the cocci. Alanine, glutamic acid, lysine and threonine were present in all walls in a molar ratio of approximately $4: I: I: I$. Both muramic acid and glucosamine were detected; the former was present in greatest amounts in the rods and least in the cystites, while the latter was greatest in the cocci and least in the cystites. In both rods and cystites, the molar ratio of glucosamine to muramic acid was about $\mathrm{I}: \mathrm{I}$, whereas in the cocci it was a little higher. The presence of more glucosamine than muramic acid has already been reported in Arthrobacter (Fiedler, Schleifer \& Kandler, 1973). The greater amount of glucosamine in the cocci may indicate that this substance is also part of the polysaccharide fraction, made up principally of glucose, galactose and rhamnose. There were slight variations in the relative proportions of these sugars in the polysaccharides of the three wall types: in cystites the molar ratio was I:I:I whereas in rods and cocci the ratios were approximately $\mathrm{I}: 3: 2$ and $\mathrm{I}: 3 \cdot 5: 3$ respectively.

The total carbohydrate content of the walls (Table I) is expressed as glucose equivalents as well as actual content because different sugars have different molar extinction coefficients in the phenol- $\mathrm{H}_{2} \mathrm{SO}_{4}$ method. Thus the $E_{488}$ values for $100 \mu \mathrm{g}$ of glucose, galactose and rhamnose in a reaction volume of $7 \mathrm{ml}$ were $0.950,0.645$ and 0.660 respectively. Despite the differences in molar ratios, polysaccharide constitutes about $60 \%$ by weight of the total wall material (Table $\mathrm{I}$ ), the remainder being peptidoglycan. The walls of cocci contained more peptidoglycan $(39 \%)$ than rods $(37.4 \%)$ and cystites $(35 \%)$.

\section{Structure}

Walls varied in thickness from 6 to $12 \mathrm{~nm}$ in rods (Fig. 7), from 6 to $40 \mathrm{~nm}$ in cystites (Fig. I0), and from Io to $27 \mathrm{~nm}$ in cocci (Fig. I); the wall appeared as a moderately electronopaque, homogeneous layer in all three forms. Beneath the wall was the cytoplasmic membrane, shown clearly in a disrupted organism (Fig. 2) where it has become detached from the wall. When the membrane was in contact with the wall, the outer membrane layer appeared thicker (Fig. I). This may be due to the presence of a periplasmic area which occasionally appears greatly enlarged, e.g. near the cross-walls at the base of buds (Figs 3,6 ). Within the enlarged periplasmic area, some ill-defined inclusions are visible.

When the organism divides, two distinct processes occur: binary fission and budding. Binary fission occurs most frequently in rods (Figs 7-9) when two daughter organisms of the same age are produced. The cross-walls are formed from double ingrowths from the inner part of the wall. When the cross-wall is complete a double structure is formed, allowing the daughter organisms to separate when the outer part of the wall fractures. What might be slight wall scars are sometimes seen (Fig. 9). The double cross-wall is about twice the thickness of the parent wall. Budding usually occurs close to a cross-wall formed by

Bar markers represent $0.2 \mu \mathrm{m}$.

Fig. 1. Cross-section of a coccus.

Fig. 2. Cross-section of a degenerating coccus showing the cytoplasmic membrane.

Figs 3-5. Stages in the budding of a coccus showing formation of a thick cross-wall and its division. Note the greater electron density of the bud, compared with the original cell in Figs 3 and 4 , and the enlarged periplasmic space.

Fig. 6. Detached bud showing prominent wall scars and enlarged periplasmic space.

$\mathrm{C}$, Cytoplasmic membrane; $\mathrm{N}$, nuclear region; $\mathrm{M}$, mesosome; $\mathrm{P}$, periplasmic space; $\mathrm{R}$, ribosomes; $\mathrm{CW}$, cross-wall; WS, wall scar. 

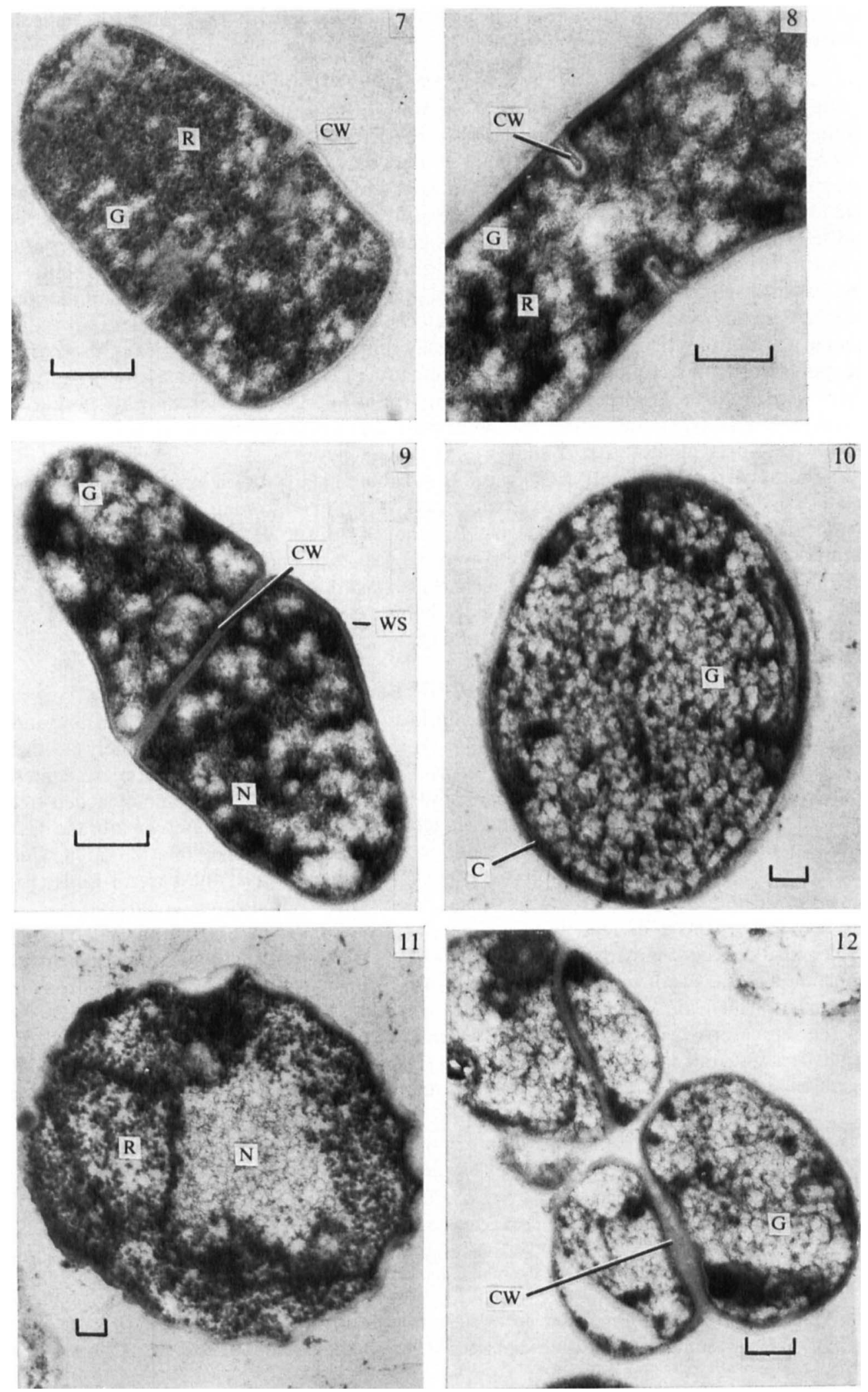
binary fission (Duxbury \& Gray, 1977), and yields a young daughter and old parent, as judged by the different nature of the cytoplasm in each. In the bud, the ribosomes are more densely packed and hence more deeply stained, mesosomes are often present and enlarged periplasmic spaces are common (Figs 3,4). The cross-wall which cuts off the bud forms by centripetal growth (Duxbury \& Gray, I977) as a single, thick structure (Fig. 3). The daughter and parent remain attached for some time until dissolution of material down the middle of the cross-wall occurs (Fig. 5) and the outer part of the parent wall ruptures, leaving prominent wall scars (Fig. 6).

The cytoplasm in rods and cocci also show some differences. Glycogen storage granules (Mulder \& Zevenhuizen, 1967; Gray, 1976) are seen in rods but never in cocci (Figs 7-9). These storage granules are even more abundant in cystites (Fig. 10) and swell the organisms to a much greater size. Occasionally, more bizarre-shaped cystites are seen with internal cross-walls and sometimes electron dense, polyphosphate-like granules (Fig. 12) or with internal membranes and irregular outlines. In the latter, the wall is partially disorganized and the organisms contain loosely packed ribosomes and nuclear material which are absent from most sections (Fig. II).

\section{DISCUSSION}

The wall of $A$. globiformis strain NCIB I 0683 has a similar chemical composition to other strains of this species which have also been found to contain lysine, alanine and glutamic acid (Fiedler et al., 1970). The presence of threonine is unusual in A. globiformis but has been reported in a number of different species considered to be $A$. globiformis (Keddie, 1974), e.g. $A$. aurescens, $A$. ureafaciens, and some other species such as $A$. citreus. Threonine, together with serine, has also been reported from $A$. oxydans and $A$. polychromogenes, also possible synonyms for $A$. globiformis.

If there are more than two alanine residues, the extra molecules are usually incorporated into the interpeptide bridge, although alanine amide may be substituted on the $\alpha$-carboxyl group of D-glutamic acid (Fiedler et al., 1970). This means that in A. globiformis NCIBI 0683, the interpeptide bridge probably contains one threonine and two alanine residues. Gray et al. (1975) have suggested that the peptidoglycan is a type 3 molecule as defined by Fiedler et al. (1973). Since the molar ratios of the amino acids are the same in the different morphological forms of $A$. globiformis NCIBI0683, it must be assumed that the ratio of the peptide sub-units to interpeptide bridges remains constant, whereas in some of the other strains, the number of interpeptide bridges or the length of the interpeptide bridges may be greater in the cocci (Krulwich et al., 1967b).

The polysaccharide, constituting about $60 \%$ of the wall material, may be responsible for the resistance to lysis of these organisms and it is interesting that Krulwich et al. (1967a) and Krulwich \& Pate (I97I) reported a phosphate, glucose, $N$-acetylglucosamine polymer in the wall of $A$. crystallopoietes in addition to the peptidoglycan. However, the sugars in the wall of $A$. globiformis NCIBI0683 are different, consisting mainly of glucose, galactose and rhamnose, and resemble those reported by Zevenhuizen (1966) in A. simplex which consisted of these same three sugars plus mannose and glucosamine. This material might protect the peptidoglycan from the action of lytic enzymes, either by layering of the wall

\section{Bar markers represent $0.2 \mu \mathrm{m}$.}

Figs 7-9. Stages in the binary fission of a rod showing formation of double cross-walls.

Fig. 10. Cross-section of a cystite packed with glycogen.

Fig. II. Infrequently observed cross-section of a cystite showing internal dividing membranes, ribosomes, a nuclear region and a distorted wall.

Fig. 12. Cross-section of a cystite showing thick cross-walls and electron-dense granules.

G, Glycogen; other abbreviations as in Figs $\mathbf{I}-6$. 
or by the linking of the sugar monomers to the peptidoglycan. Pengra, Cole \& Alexander (I969) have suggested a similar mechanism to explain the resistance of some fungal walls to lysis by glucanase-chitinase mixtures.

The location of the sugars, possibly as a polymer in the wall, is not clear. There is little evidence for the presence of distinct layers, although the presence of wall scars suggests that the outer part of the wall is fractured rather than cleaved during division. Krulwich \& Pate (I97I) suggested that it was the sudden rupturing of an outer wall which gave rise to snapping post-fission movements in $A$. crystallopoietes. These movements have not been observed in the present organism but bending division is common and Duxbury \& Gray (1977) have suggested that the differences in type of division may be due to differences in elasticity in the outer part of the wall. Changes in thickness of the walls do not correspond with changes in chemical composition, but Luscombe \& Gray (1974) have shown that cocci survive longer than rods in nutrient-free buffer.

The different types of cross-wall associated with binary fission and budding correspond with those described by Williams, Sharples \& Bradshaw (I973) in streptomycetes. They found double cross-walls associated with sporulation and suggested that their function was to ensure the production of easily separable fragments. They also found single crosswalls, most commonly in stable vegetative mycelium where they sealed off hyphal portions. The effects of the different cross-walls are similar in Arthrobacter in that budding leads to slower separation of cells, often by bending division, while binary fission allows rapid separation. The reasons for such differences must await further study.

The occurrence of more densely packed ribosomes and the presence of mesosomes in one of a pair of budding organisms suggests that growth and metabolism are localized in the young bud, as it is formed from an ageing parent. Presumably, the bud can draw on reserves from the parent, even when the external supply of nutrients is very low. The presence of a periplasmic area may be due to protoplast shrinkage during preparation for electron microscopy but the localization of the enlarged spaces is unusual. Novitsky \& Morita (1976) have found enlarged periplasmic areas in Vibrio but these were in starved organisms rather than actively growing ones. One explanation for enlarged periplasmic spaces is that they are visible only in oblique sections.

The main reserve material is an electron transparent material related to glycogen (S. J. Chapman, personal communication). Glycogen occurs in organisms grown in media with a high carbon nitrogen ratio (Zevenhuizen, I966) and hence cystites are forms in which glycogen has distended the organism. If glycogen is produced in natural conditions, for example from decomposing plant material where the carbon to nitrogen ratio may also be high, then it is important that the wall be flexible to allow expansion. The apparent absence of ribosomes from most sections of cystites may be explained by assuming that they are displaced to the ends of the cell and it is noticeable that it is at the cell poles where outgrowth of cystites often takes place (Duxbury \& Gray, 1977).

We wish to thank the Science Research Council for grants enabling us to carry out this work.

\section{REFERENCES}

AlleN, R. J. L. (1940). The estimation of phosphorus. Biochemical Journal 34, 858-865.

Chaplin, C. E. (1957). Life cycles in Arthrobacter pascens and Arthrobacter terregens. Canadian Journal of Microbiology 3, 103-106.

Dubois, M., Gilles, K. A., Hamilton, J. K., Rebers, P. A. \& SMith, F. (1956). Colorimetric method for the determination of sugars and related substances. Analytical Chemistry 28, $350-356$.
Duxbury, T. \& Gray, T. R. G. (1977). A microcultural study of the growth of cystites, cocci and rods of Arthrobacter globiformis. Journal of General Microbiology ro3, IOI-I06.

Fiedler, F., Schleifer, K. H., Cziharz, G., INTERSCHICK, E. \& Kandler, O. (I970). Murein types in Arthrobacter, brevibacteria, corynebacteria and microbacteria. Publications of the Faculty of Science of the University of J. E. Purkyne, Brno 47, I I I-I22. 
Fiedler, F., Schleifer, K. H. \& Kandler, O. (1973). Amino acid sequence of the threoninecontaining mureins of coryneform bacteria. Journal of Bacteriology 113, 8-17.

Gehrke, C. W., Roach, D., Zumwalt, R. W., StalLING, D. L. \& WALL, L. L. (I968). Quantitative Gas-liquid Chromatography of Amino Acids in Proteins and Biological Substances. Columbia, Missouri: Analytical Biochemistry Labs.

Gray, T. R. G. (1976). Survival of vegetative microbes in soil. Symposia of the Society for General Microbiology 26, 327-364.

Gray, T. R. G., Duxbury, T., Luscombe, B. M. \& Chapman, S. J. (1975). Arthrobacter globiformis, a successful soil bacterium. Proceedings of the Ist Intersectional Congress of the International Association of Microbiological Societies 2, 262276.

Herbert, D., Phipps, P. J. \& Strange, R. E. (I97I). Chemical analysis of microbial cells. Methods in Microbiology 5B, 209-344.

Holligan, P. M. \& Drew, E. A. (197I). Routine analysis of gas-liquid chromatography of soluble carbohydrates in extracts of plant tissues. II. Quantitative analysis of standard carbohydrates and the separation and estimation of soluble sugars and polyols from a variety of plant tissues. New Phytologist 7o, 27I-297.

Keddie, R. M. (1974). Genus II. Arthrobacter Conn and Dimmick 1947, 300. In Bergey's Manual of Determinative Bacteriology, 8th edn, pp. 618-625. Edited by R. E. Buchanan and N. E. Gibbons. Baltimore: Williams \& Wilkins.

Krulwich, T. A. \& PATe, J. L. (I97I). Ultrastructural explanation for snapping post-fission movements in Arthrobacter crystallopoietes. Journal of Bacteriology 105, 408-4I2.

Krulwich, T. A., Ensign, J. C., Tipper, D. J. \& Strominger, J. L. (1967a). Sphere-rod morphogenesis in Arthrobacter crystallopoietes. I. Cell wall composition and polysaccharides of the peptidoglycan. Journal of Bacteriology 94, 734740.

Krulwich, T. A., Ensign, J. C., Tipper, D. J. \& Strominger, J. L. (1967b). Sphere-rod morphogenesis in Arthrobacter crystallopoietes. II. Peptides of the cell wall peptidoglycan. Journal of Bacteriology 94, 74I-750.

LochHeAD, A. G. \& BuRToN, M. O. (I954). Qualitative studies of soil microorganisms. XII. Characteristics of vitamin $\mathrm{B}_{12}$-requiring bacteria. Canadian Journal of Microbiology r, 3 19-330.

LowE, W. E. \& GRAY, T. R. G. (1972). Ecological studies on coccoid bacteria in a pine forest soil - I. Classification. Soil Biology and Biochemistry 4, 459-467.
LUSCOMBE, B. M. \& Gray, T. R. G. (197I). Effect of varying growth rate on the morphology of Arthrobacter. Journal of General Microbiology 69, 433-434.

Luscombe, B. M. \& Gray, T. R. G. (1974). Characteristics of Arthrobacter grown in continuous culture: Journal of General Microbiology 82, 213-222.

Mulder, E. G. \& Antheunisse, J. (1963). Morphologie, physiologie et écologie des Arthrobacter. Annales de l'Institut Pasteur 104, 46-74.

Mulder, E. G. \& Zevenhuizen, L. P. T. M. (1967). Coryneform bacteria of the Arthrobacter type and their reserve material. Archiv für Mikrobiologie 59, 345-354.

Novitsky, J. A. \& Morita, R. Y. (I976). Morphological characterization of small cells resulting from nutrient starvation of a psychrophilic marine vibrio. Applied and Environmental Microbiology 32, 6I 7-622.

Owens, J. D. \& Keddie, R. M. (1969). The nitrogen nutrition of soil and herbage coryneform bacteria. Journal of Applied Bacteriology 32, 338-347.

Pengra, R. M., Cole, M. A. \& Alexander, L. (I969). Cell walls and lysis of Mortierella parvispora hyphae. Journal of Bacteriology 37, 1056I061.

REYNOLDS, E. S. (1963). The use of lead citrate at high $\mathrm{pH}$ as an electron-opaque stain in electron microscopy. Journal of Cell Biology 17, 208-2 I 2.

Salton, M. R. J. (1964). The Bacterial Cell Wall. Amsterdam: Elsevier.

SPURR, A. R. (1969). A low-viscosity epoxy resin embedding medium for electron microscopy. Journal of Ultrastructural Research 26, 3I-43.

Stevenson, I. L. (I963). Some observations of the so-called 'cystites' of the genus Arthrobacter. Canadian Journal of Microbiology 9, 467-472.

STEWART-Tull, D. E. S. (I968). Determination of amino sugars in mixtures containing glucosamine, galactosamine and muramic acid. Biochemical Journal ro9, 13-I8.

Williams, S. T., Sharples, G. S. \& Bradshaw, R. M. (1973). The fine structure of the Actinomycetales. In The Actinomycetales: Characteristics and Importance, pp. I13-130. Edited by G. Sykes and F. A. Skinner. London and New York: Academic Press.

Work, E. (1971). Cell walls. Methods in Microbiology 5A, 36r-418.

Zevenhuizen, L. P. T. M. (1966). Function, structure and metabolism of the intracellular polysaccharide of Arthrobacter. Mededelingen van de Landbouwhoogeschool te Wageningen 66-10, I-80. 